Renata STOCZKOWSKA

Maria OBRĘBSKA

Ryszard KOWALSKI

Magdalena MALUCHNIK-PUCEK

AP Siedlce

\title{
Nieformalna edukacja środowiskowa na przykładzie regionalnej prasy w województwie lubelskim
}

Edukacja pozaszkolna, określana też jako nieformalna, prowadzona przez różne instytucje i organizacje, wzbogaca, uzupełnia i wspiera działania planowe prowadzone w szkołach. Jej prowadzenie może odegrać ważną rolę w przeobrażaniu świadomości społecznej w kierunku proekologicznym (Kiełczewski, 2001; Sarzała, 2005). W wielu dokumentach międzynarodowych i krajowych konferencji, raportach opracowanych przez różne instytucje, towarzystwa naukowe, organizacje społeczne, zaleca się, aby cele ekologiczne osiągać łącząc działania szkolne i pozaszkolne (Cichy, 1996; Kozłowska, 1997). Edukacja prowadzona poza szkołą może objąć osoby w różnym wieku - dzieci, młodzież i dorosłych i w odróźnieniu od edukacji szkolnej towarzyszy jednostce przez całe życie.

Aby skutecznie przeciwdziałać problemom środowiskowym, potęgującym się we współczesnym świecie, trzeba stosować w edukacji ekologicznej takie środki oddziaływania na społeczeństwo, które zapewnią szybki przepływ informacji i sprawne komunikowanie się na odległość. Takim celom dobrze służą media (Krzyśko, 1998) i jak wykazują badania, mają one znaczący wpływ na poziom wiedzy ludzi o stanie środowiska naturalnego (Ministerstwo Środowiska, 2001). O miejscu prasy w nieformalnej edukacji środowiskowej decyduje czynnik powszechnego dostępu, a poprzez to duża możliwość dydaktycznego, opiniotwórczego i kulturowego oddziaływania.

W Narodowej Strategii Edukacji Ekologicznej (Ministerstwo Środowiska, 2001) zwraca się uwagę na to, iź środki masowego przekazu powinny:

- „W sposób rzetelny, bez poszukiwania sensacji, przedstawiać stan środowiska naturalnego i prezentować pozytywne przykłady działań podejmowanych na rzecz jego ochrony, pokazując również skutki (w tym finansowe) zamierzonych i niezamierzonych działań prowadzonych w środowisku, 
- Promować style życia i zachowania przyjazne środowisku,

- Nawiązywać bliską współpracę z instytucjami i organizacjami zajmującymi się ochroną środowiska w celu zdobywania i gromadzenia informacji oraz korzystania z prowadzonych przez nie działań,

- Dążyć do odkomercjalizowania mediów w zakresie upowszechniania wiedzy o środowisku,

- Ograniczyć lansowanie cywilizacji konsumpcyjnej”.

Prasa codzienna zajmując się różnorodną tematyką i przedstawiając fakty i opinie prostym językiem, może docierać do szerokiego grona odbiorców, w odróżnieniu od czasopism naukowych, pisanych w sposób trudny, zrozumiały dla wąskiej grupy specjalistów. Mając możliwość podawania ważnych informacji z zakresu tematyki środowiskowej, prasa może podnosić poziom wiedzy, kształtować opinie i prośrodowiskowe postawy. Artykuły opisujące zjawiska przyrodnicze czy działania ludzi na rzecz poprawy stanu środowiska mogą w różnorodny sposób wpływać na stosunek ludzi do środowiska: informować, zachęcać do działania, uwrażliwiać, piętnować negatywne zachowania itp. Odpowiednie zaangażowanie środków masowego przekazu w informowanie społeczeństwa o wartości środowiska przyrodniczego i problemach jego ochrony, może przyczynić się do skuteczniejszego wychowania i poprawienia niekorzystnych dziś relacji człowieka z przyrodą.

Celem niniejszej pracy było określenie zaangażowania regionalnej prasy w edukację ekologiczną społeczeństwa. Starano się go osiągnąć poprzez analizę dwóch wybranych tytułów prasowych ukazujących się w województwie lubelskim. Analizie poddano dwa dzienniki: „Kurier Lubelski” i „Dziennik Wschodni” z lat 2003 - 2004. Eącznie przeanalizowano 1216 numerów gazet. Typując tytuły gazet do badań kierowano się wielkością ich nakładu i zasięgiem. Wybrane do analiz dzienniki są źródłem bieżących informacji społecznych, politycznych, gospodarczych, w tym informacji o problemach związanych ze środowiskiem przyrodniczym.

„Kurier Lubelski” to najstarszy dziennik na Lubelszczyźnie. Po raz pierwszy ukazał się w 1830 roku, zaś regularnie jest wydawany od roku 1959. Zasięg gazety rozciąga się na całe województwo lubelskie.

„Dziennik Wschodni” to pismo informacyjno - publicystyczne. Swoim zasięgiem obejmuje całe województwo lubelskie, a także powiat łosicki w województwie mazowieckim.

Przystępując do badań postawiono następującą hipotezę: Prasa w województwie lubelskim prowadzi nieformalną edukację środowiskową, jednak nie w pełni wykorzystuje swój potencjał i środki, którymi dysponuje, by kształcić społeczeństwo w tym zakresie. 


\section{Analiza i interpretacja wyników badań}

Przygotowując pracę przeanalizowano 608 numerów jednej i tyle samo drugiej gazety z lat 2003-2004. W sumie stwierdzono 1136 artykułów nawiązujących do tematyki przyrodniczej, geograficznej prozdrowotnej i sozologicznej, które ogólnie określono pojęciem środowiskowe.

Analiza porównawcza wyników badań wykazała, że w obydwu latach tematyka przyrodnicza częściej była podejmowana przez „Kurier Lubelski”. Teksty przyrodnicze zamieszczane były zarówno $\mathrm{z}$ inicjatywy redakcji, jak i czytelników - jako odpowiedzi na ich listy. Obie gazety zwiększyły w 2004 roku liczbę i objętość artykułów nawiązujących do ww. problematyki w stosunku do roku poprzedniego, co pozytywnie rokuje na przyszłość i świadczy o wzroście zapotrzebowania społecznego tą tematyką (ryc.1).

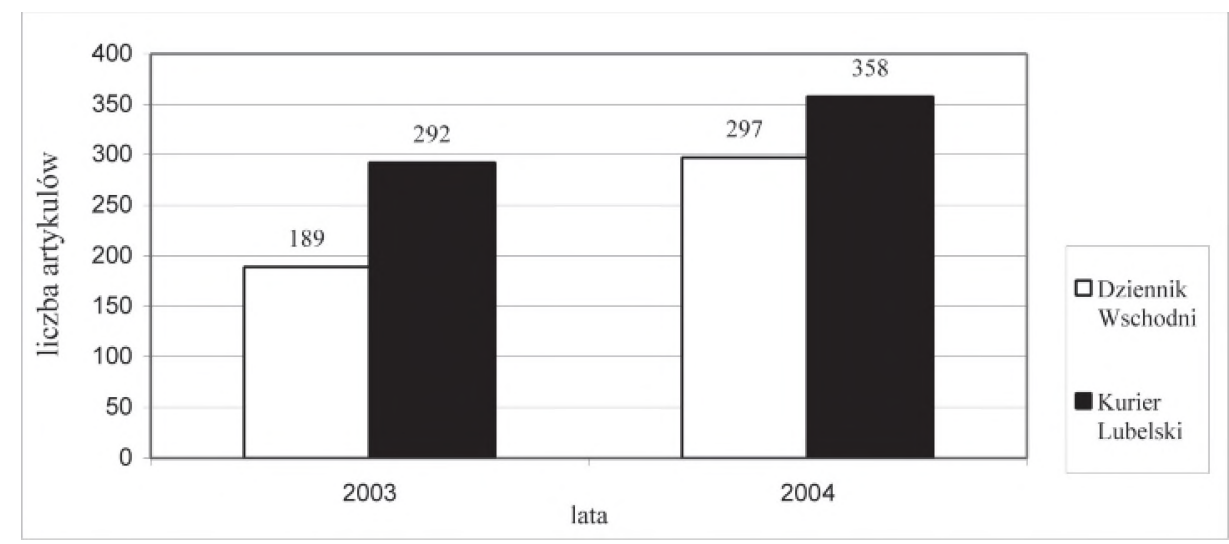

Ryc. 1. Artykuly środowiskowe w regionalnej prasie w województwie lubelskim w latach 2003-2004 $(N=1136)$

Teksty przyrodnicze lub wykorzystujące motywy przyrodnicze do opisywania zjawisk społecznych ukazywały się w obu dziennikach z różną częstotliwością, zazwyczaj kilkanaście do kilkudziesięciu razy w miesiącu.

Z przeprowadzonych badań wynika, że fenologiczne zmiany w środowisku przyrodniczym przekładają się na liczbę i tematykę artykułów prasowych. Zarówno w jednej jak i w drugiej gazecie miesiące zimowe charakteryzowała najniższa liczba artykułów przyrodniczych. Największa liczba artykułów odnoszących się do przyrody przypadła na miesiące od marca do października osiągając wartości maksymalne w różnych miesiącach w zależności od tytułu prasowego i roku (ryc.2). 


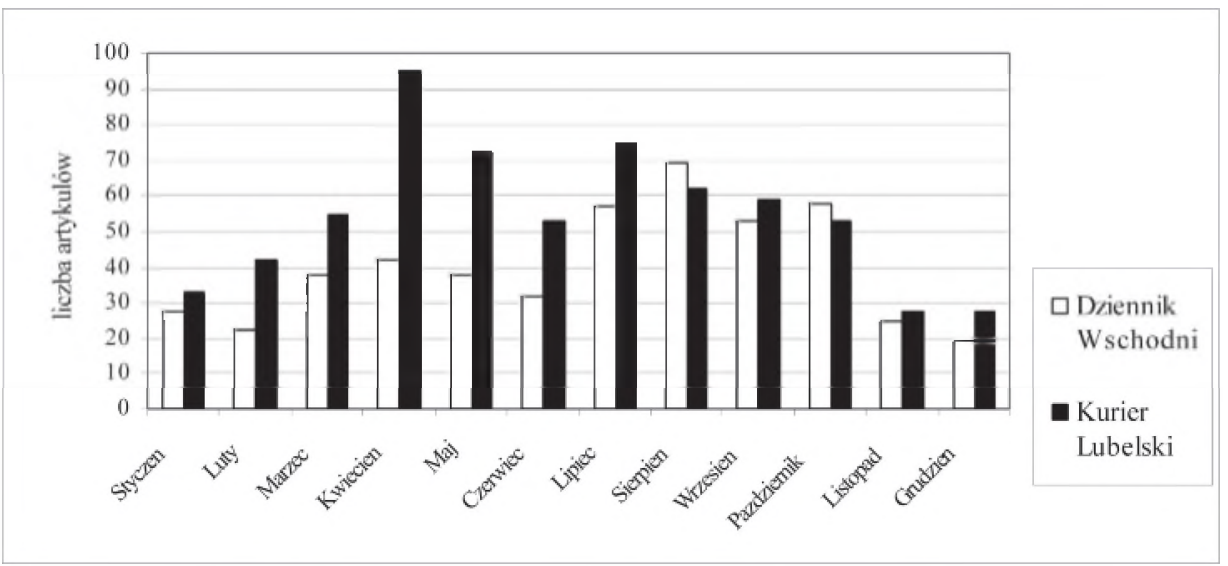

Ryc. 2. Rozkład tematyki środowiskowej artykułów prasowych w poszczególnych miesia$\operatorname{cach}(N=1136)$

Rozpatrując charakter artykułów środowiskowych, w obu tytułach prasowych odnotowano dominację treści informacyjnych. Artykuły informacyjne podawały bieżące wiadomości takie jak np:

- Dane o stanie środowiska przyrodniczego (stan powietrza w Lublinie, stan wody w Zalewie Zemborzyckim, jakość wody pitnej w regionie, zniszczenia rezerwatu na górkach Czechowskich, relacje $\mathrm{z}$ interwencji podczas katastrof drogowych, wyczerpywanie się nieodnawialnych zasobów przyrody);

- Wydarzenia spoleczne z kontekstem przyrodniczym (protesty przeciwko budowie obwodnicy, sortowni odpadów, wysypisku odpadów, sortowni śmieci, spalarni, przeciwko budowie nadajnika gsm, sprzeciw wobec koncepcji wybudowania hipermarketu na górkach Czechowskich, ostrzeżenie przed paleniem w piecach podkładów kolejowych);

- inwestycje na rzecz środowiska (otwarcie zakładów prowadzący odzysk materiałowy z opon samochodowych, modernizacja kopalni, cementowni, wodociągów, kotłowni; instalowanie kolektorów słonecznych, termomodernizacja budynków szkolnych, a także ustawianie pojemników do zbiórki odpadów niebezpiecznych i zabezpieczenie lessowego jaru przed erozją, źródła finansowania inwestycji ekologicznych w Polsce);

- Inicjatywy i wydarzenia lokalne o wydźwięku środowiskowym (nagroda dla miasta Puławy w konkursie Lider Polskiej ekologii, nagroda w Konkursie Liga Inicjatyw Powiatowych dla miasta Krasnystaw, sprzątanie miasta; walka ze szrotówkiem);

- Promocja regionu (miód, agroturystyka, zachęcanie do uprawiania turystyki w regionie, barwne opisy przyrody i krajobrazu w regionie); 
- Opisy zjawisk fenologicznych (uroki poszczególnych pór roku)

- Ciekawostki ze świata roślin i zwierząt (rośliny owadożerne, zachowania zwierząt dzikich lub oswojonych, szkody wyrządzone przez bobry);

Specjalnością „Dziennika Wschodniego” były różnego rodzaju porady mówiące o tym jak można uniknąć przykrych skutków ukąszeń owadów lub w jaki sposób suszyć zioła, zaś „Kurier Lubelski” zamieszczał dużą liczbę artykułów o charakterze redakcyjnych interwencji, najczęściej dotyczące problemu odpadów - dzikich wysypisk w środku miasta i w lasach, jak również zaniedbanych brzegów Bystrzycy, czy niszczenia trawników przez auta.

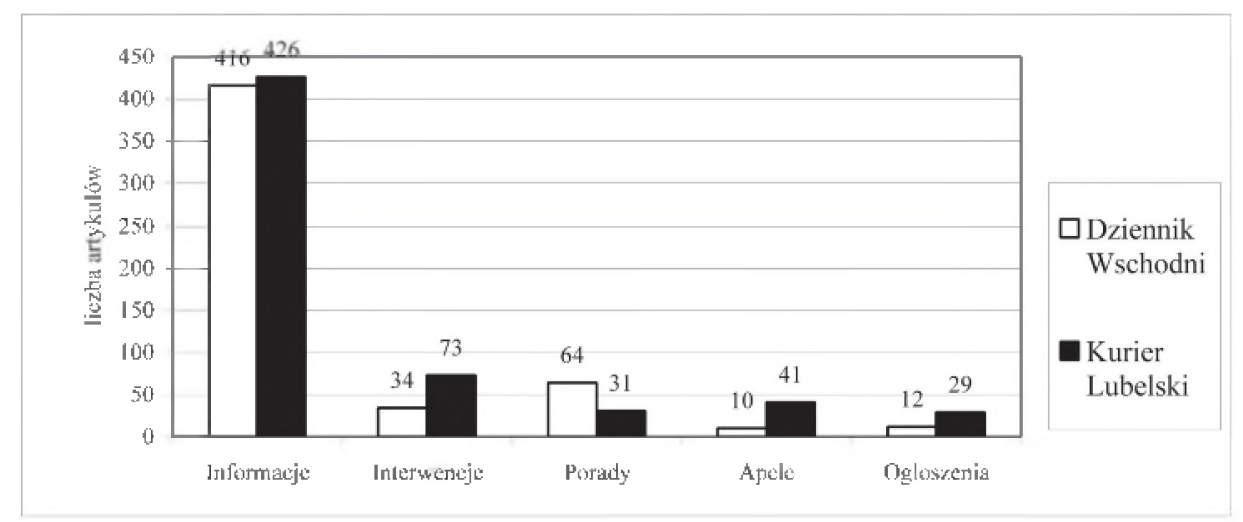

Ryc. 3. Artykuly środowiskowe wg rodzajów $(N=1136)$

Najniższy odsetek stanowiły w „Dzienniku Wschodnim” apele i ogłoszenia, a w „Kurierze Lubelskim” ogłoszenia i porady. Wśród wydrukowanych apeli znalazły się między innymi teksty zachęcające do ochrony płazów czy udziału w akcji opieki nad lubelskimi kasztanowcami. Ogłoszenia dotyczyły głównie organizowanych wystaw i konkursów (ryc. 3).

Analiza porównawcza według dyscypliny biologicznej ujawniła, że tematyka artykułów przyrodniczych podejmowanych przez „Dziennik Wschodni” i „Kurier Lubelski" była różnorodna (rys.4). Najpopularniejsza w obu tytułach prasowych okazała się tematyka zoologiczna w kontekście użyteczności zwierząt. Zamieszczano m.in. różnorodne informacje o zwierzętach domowych (porady dotyczące hodowli, tresury), a także zwierząt dzikich (występowanie, zachowanie) oraz wiele informacji na temat życia zwierząt w ZOO. Dużą uwagę poświęcano ogłoszeniom o zwierzętach, dotyczących na przykład: wystawy ptaków egzotycznych lub oferty typu „oddam w dobre ręce”. Najwięcej artykułów zoologicznych ukazało się w „,Kurierze Lubelskim” w 2004 roku.

Ważne miejsce zajęly też artykuły botaniczne opisujące świat roślin, także w aspekcie ich uprawy w ogrodach (ryc.4). Największą liczbę artykułów z tej dyscypliny biologicznej i we wspomnianych wyżej kontekstach zamieścil „Dziennik 
Wschodni" w 2004 roku. Artykuły florystyczne w aspekcie użytkowym i uprawowym instruowały najczęściej o tym jak urządzać ogród.

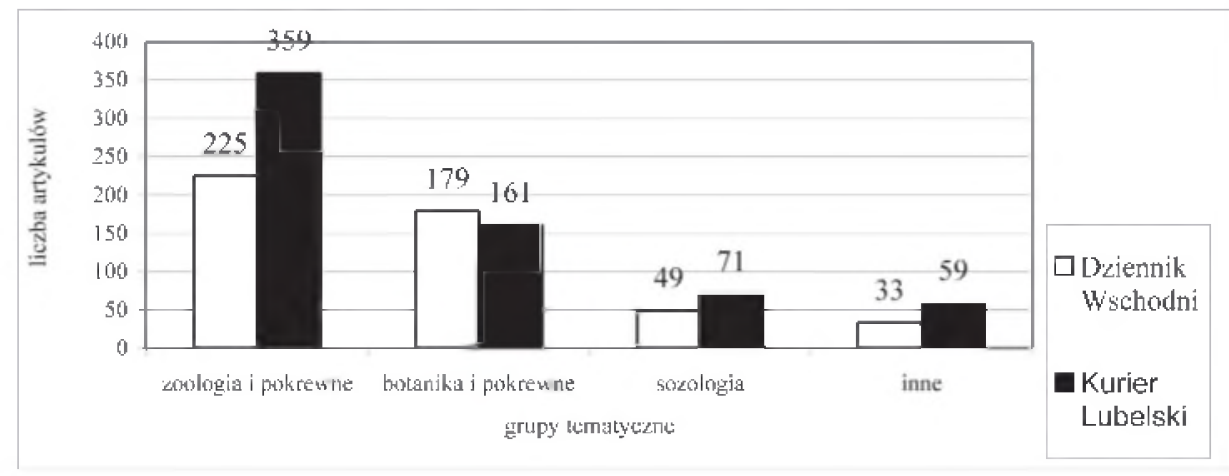

Ryc. 4. Artykuły przyrodnicze wedtug dyscypliny biologicznej

Rzadziej zamieszczane były w analizowanych gazetach artykuły sozologiczne (ryc.4). Miały one różny charakter i dotyczyły zarówno ochrony przyrody jak i środowiska:

1. Ochrona przyrody

- opisy form ochrony przyrody i innych obszarów cennych przyrodniczo (Rezerwat Piskory, Lasy Sobiborskie),

- promowanie ochrony gatunkowej (potępianie zabijania lub przemycania dzikich zwierząt lub przedmiotów z nich wykonanych, ochrona płazów, gadów i małych ssaków, bobrów)

2. Ochrona środowiska

- stan środowiska w regionie - wód (wyniki badań wody Zalewu Zemborzyckiego, wody pitnej i powietrza w Lublinie,

- inwestycje na rzecz środowiska (modernizacja kopalni, cementowni i wodociągów, oczyszczanie jezior, montowanie baterii słonecznych),

- zachęcanie do wdrażania prośrodowiskowych rozwiązań (alternatywnych źródeł energii, modernizacji CO, zakładania rozdrabniaczy odpadów organicznych),

- negatywne przykłady wpływu działalności ludzkiej na środowisko (katastrofy drogowe, dewastacje ekosystemów),

- problem odpadów (zaśmiecenie, nielegalne wysypiska, zakaz spalania odpadów),

- kwestie sporne (protesty związane z budową sortowni i obwodnicy dla Lublina, spór o Górki Czechowskie, czy zarybienie Zalewu Zemborzyckiego w celu pozbycia się sinic).

Zagadnieniom sozologicznym poświęcono mniej miejsca w analizowanych tytułach prasowych niż tematom pozostałym. „Dziennik Wschodni” i „Kurier 
Lubelski", jako gazety codzienne mające szeroki zakres zainteresowań, nie zajmują się w sposób stały edukowaniem społeczeństwa w zakresie ekologii i ochrony środowiska. Może wynika to również z faktu, że problemów środowiskowych na Lubelszczyźnie, które mogłyby być opisywane w formie sensacyjnych doniesien jest stosunkowo niewiele.

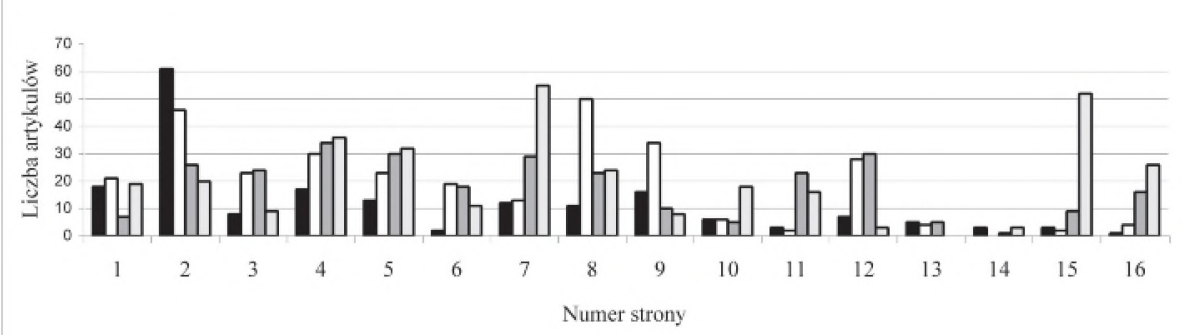

Dziennik Wschodni $2003 \square$ Dziennik Wschodni $2004 \square$ Kurier Lubelski $2003 \square$ Kurier Lubelski 2004

Ryc. 5. Liczba artykulów środowiskowych na poszczególnych stronach gazet

Analiza porównawcza rangi tematyki środowiskowej, mierzonej miejscem przydzielonym na poszczególnych stronach gazet wykazała, że nie jest jej poświęcona konkretna stała strona lub kolumna w gazecie. O tym, na której stronie ukazują się teksty środowiskowe, w dużej mierze decyduje ich charakter i forma dziennikarska. W analizowanych tytułach prasowych treści te publikowane były na różnych stronach. W „Dzienniku Wschodnim” największa liczba tego typu artykułów znalazła się na drugiej stronie, zaś w „Kurierze Lubelski” na stronie siódmej. Na pierwszej stronie, która w każdej gazecie jest najważniejsza, przede wszystkim ze względów marketingowych, ale także świadczy o misji danego tytułu prasowego, artykuły środowiskowe również się pojawiały, choć w dużej mierze były to tylko zapowiedzi i reklamy tego, co zamieszczono w środku wydania (ryc.6)

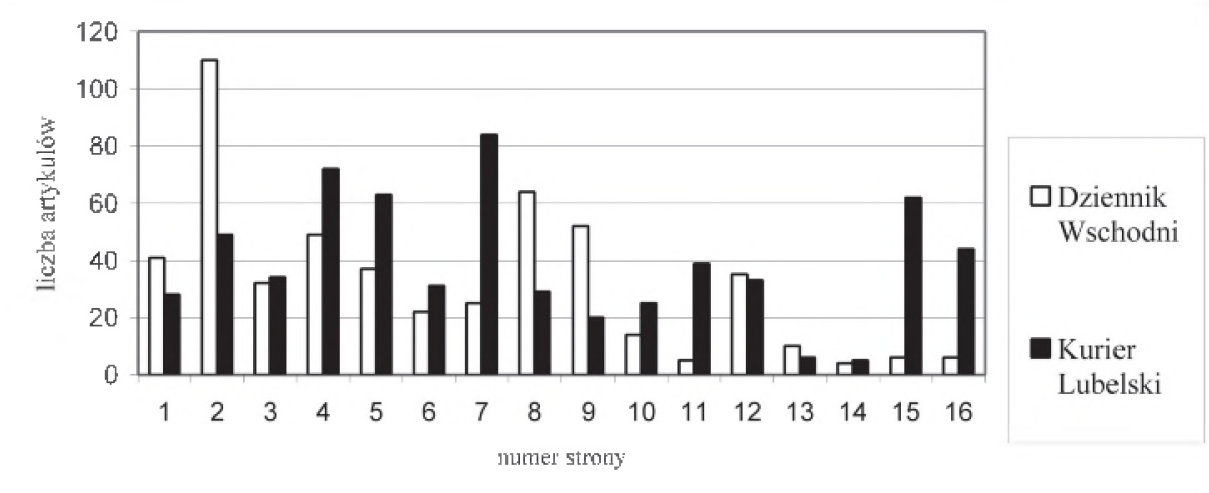

Ryc.6. Liczba artykułów środowiskowych na poszczególnych stronach gazet 
Na uwagę zasługuje dobór materiału ilustracyjnego. Kolorowe bądź czarno-białe fotografie i rysunki przedstawiały różne gatunki roślin, zwierząt, a także tereny atrakcyjne pod względem przyrodniczym, co uzupełniało prawie każdy tekst w obydwu analizowanych gazetach i przyciągało uwagę czytelnika. W „Dzienniku Wschodnim” w 2003 roku na 189 artykułów i doniesień przyrodniczych, tylko 18 nie było ilustrowanych. Porównując liczbę fotografii i rysunków $\mathrm{w}$ analizowanych tytułach prasowych w obrębie 2 lat stwierdzono największą ogólną ich liczbę (285) w „Kurierze Lubelskim” w roku 2004. W obydwóch gazetach najczęściej zestawiano tekst $\mathrm{z}$ jedną ilustracją, choć zdarzały się też takie przypadki, kiedy w jednym wydaniu znajdowało się powyżej sześciu zdjęć przyrodniczych (ryc. 7).

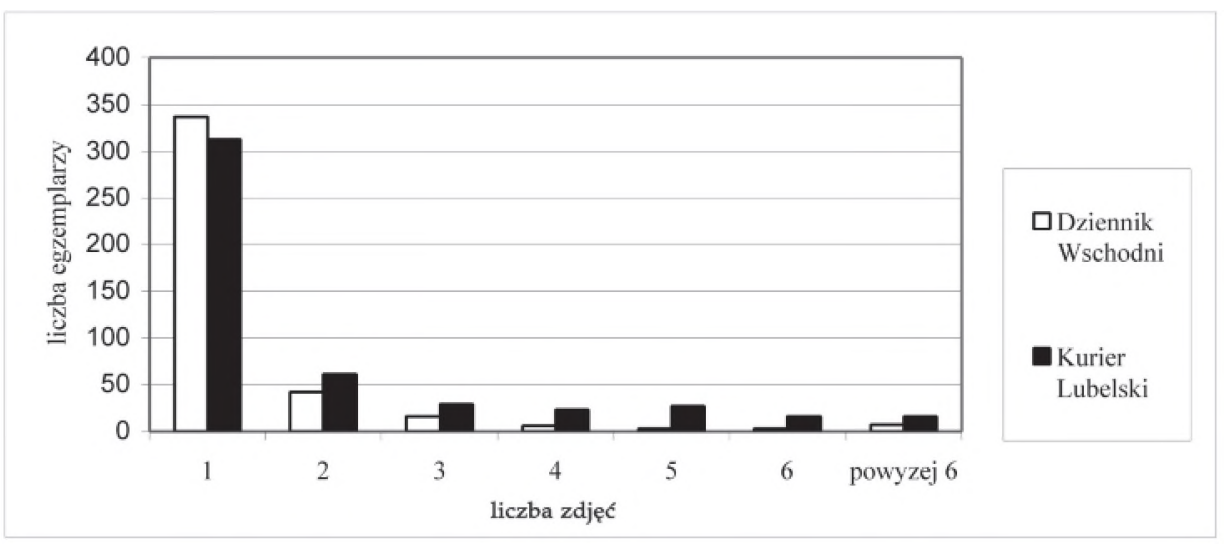

Ryc. 7. Materiał ilustracyjny w artykułach środowiskowych (liczba zdjęć na 1 wydanie gazety)

\section{Podsumowanie i wnioski}

Wyniki badań pochodzące $\mathrm{z}$ analizy dwóch roczników Kuriera Lubelskiego i Dziennika Wschodniego pozwoliły na sformułowanie następujących wniosków:

1. Analizowane gazety, mające zasięg regionalny, realizują edukację ekologiczną w znaczeniu popularyzacji tematyki przyrodniczej, środowiskowej, geograficznej i zdrowotnej. Prezentowana jest ona najczęściej w formie artykułów będących: relacją $\mathrm{z}$ aktualnych wydarzeń mających kontekst środowiskowy i poruszających społeczność lokalną, opisem zjawisk fenologicznych lub poradą.

2. Można zauważyć wzrost rangi tematyki przyrodniczej, ekologicznej i środowiskowej przejawiający się w coraz większej liczbie zamieszczanych artykułów, doniesień i wzmianek związanych z przyrodą i środowiskiem i potrzebą ich ochrony. 
3. Niekorzystna jest pewna sezonowość w publikowaniu treści przyrodniczych i brak ich wyraźnego umiejscowienia w strukturze gazety. Wydaje się celowe stałe (w każdym numerze, w wybrany dzień tygodnia lub jako dodatek) publikowanie nawet krótkich artykułów o charakterze środowiskowym, aby przyzwyczaić czytelników szukających informacji o środowisku do ich czytania. Stałe zwracanie uwagi na problemy ekologiczno-sozologiczne może zainteresować nimi czytelników i przekonać, że są one tak samo ważne jak inne tematy społeczne, polityczne czy gospodarcze

4. Prasa codzienna mogłaby realizować edukację środowiskową w sposób pełniejszy gdyby zamieszczane w niej artykuły bardziej służyły wyjaśnianiu problemów środowiskowych i pogłębianiu ich zrozumienia, akcentowały odpowiedzialność za zmiany dokonywane w środowisku kształtując przy tym całościowy obraz relacji pomiędzy człowiekiem, społeczeństwem i przyrodą, a nie koncentrowały się głównie na ciekawostkach ze świata roślin i zwierząt.

5. Jeśli prasa realizując swoją społeczną misję chce być bardziej skuteczna w edukacji środowiskowej, powinna jak najczęściej promować wartość przyrody, zachęcać do jej ochrony i wypoczynku na łonie natury, w czystym otoczeniu.

6. Biorąc pod uwagę fakt, że problemy związane z degradacją przyrody i środowiska i zależnością między człowiekiem i środowiskiem dotyczą wszystkich ludzi, prasa powinna ukazywać tematykę środowiskową wieloaspektowo, docierając do czytelników mających różne zainteresowania i wiedzę. Częste, systematyczne publikowanie artykułów przyrodniczych i sozologicznych może zachęcić czytelników do działania na rzecz środowiska.

7. Regionalna prasa uczestniczy w nieformalnej edukacji środowiskowej, ale nie nadaje jej jeszcze zbyt wysokiej rangi w hierarchii opisywanych problemów, a w zakresie informowania społeczeństwa nie wykorzystuje jeszcze w pełni posiadanego potencjału.

\section{Literatura}

1. Cichy D., 1996: Program edukacji środowiskowej. Teoria i praktyka. Materiały z konferencji 24-26.04.1996 r. Radziejowice. Instytut Badań Edukacyjnych. Warszawa-Skierniewice.

2. Kiełczewski D., 2001: Ekologia społeczna. Wydawnictwo Ekonomia i Srodowisko. Białystok.

3. Kozłowska I., 1997: Edukacja ekologiczna studentów. W: Problemy dydaktyki i wychowania w Akademii Rolniczej w Poznaniu. Wydawnictwo Akademii Rolniczej w Poznaniu.

4. Krzyśko M.,1998: Ocena środków dydaktycznych wspomagających edukację środowiskową. W: II Międzynarodowa Konferencja Media a edukacja. Wydawnictwo eMPi2. Poznań.

5. Ministerstwo Środowiska, 2001: Struktura pozaszkolnej edukacji ekologicznej. W: Przez edukację do zrównoważonego rozwoju. Narodowa Strategia Edukacji Ekologicznej. Wydawnictwo Ministerstwa Środowiska. Warszawa.

6. Nowak L., Żeber-Dzikowska I., 1998: Nieformalna edukacja środowiskowa i jej rola w kształceniu dorosłych. W: Kształcenie ekologiczne dorosłych. Zeszyty naukowe 23, Polska Akademia Nauk, Komitet Naukowy Przy Prezydium PAN „Czlowiek i Srodowisko” pod redakcją Cichy D. 
7. Sarzała D., 2005: Koncepcja zrównoważonego rozwoju w aspekcie pedagogicznym. W: Problemy XXI wieku prawo ochrony środowiska, edukacja środowiskowa i agrobiznes. Wydawnictwo Uniwersytetu Kardynała Stefana Wyszyńskiego. Warszawa.

\title{
Informal environmental education on example of regional press in lubelskie province
}

\author{
SUMMARY
}

The press fulfills important role if it comes to culture, it also influences the public opinion. Therefore, it can be an important tool in forming the view of society according to the problems of degradation and protection of natural environment. The aim of this article is to estimate engagement of the regional press on the example of lubelskie province. The hypothesis is that the regional daily press in lubelskie province lead informal environmental education, however, they do not use their potential and means in order to form pro- ecological attitudes and opinions among its readers. The results of research have shown that the number of articles about nature has systematically increased comparing to other thematic ranges, which is a very positive fact. However, the texts which are sensational and do not touch the problem still prevail in the press. There are not enough articles that present natural environment as a value which should be protected because of economic, spiritual, healthy and esthetic reasons. Taking into account that the problems connected with degradation and protection of nature ought to be treated as priority, the local press should involve in the environmental education much stronger. They can get through to the readers by interesting and convincing articles, and contribute to improvement of the natural environment. 